\title{
Local Contingencies in L2 Tasks: A Comparison of Context-Sensitive Interactional Achievements across Two Different Task Types
}

\author{
Ufuk Balaman ${ }^{1}$ \& Olcay Sert ${ }^{2}$ \\ ${ }^{1}$ Hacettepe University, Ankara, Turkey \\ ${ }^{2}$ Mälardalen University, Västerås, Sweden
}

Article received 8/09/17, final version 23/09/17

DOI: https://doi.org/10.5565/rev/jt13.746

\begin{abstract}
Recent research on L2 interaction and interactional competencies shows that L2 learners deploy a great diversity of interactional resources and adapt their talk to context-sensitive differences in various institutional settings. Although there is a growing interest in how these resources vary in different settings, comparative investigations into the interactional mechanisms in different contexts is scarce. With this mind, using Conversation Analysis, this study sets out to provide a snapshot of how a focal L2 learner manifests an observable diversity in task openings of a face-to-face discussion task and an online emergent information gap task. We focus on the first encounters with these two task types and settings and describe participant orientations to context-sensitive conduct on a turn-by-turn basis. The findings demonstrate differences in turn taking, allocation and design as well as in action formation, thus contributing to L2 interactional competence research based on comparative analyses of two single cases.
\end{abstract}

Keywords: Conversation analysis; task-oriented interaction, L2 interactional competence, context sensitivity, task types

\begin{abstract}
Resumen
Investigaciones recientes sobre la interacción en la L2 y las competencias interacciónales muestran que los alumnos de L2 despliegan una gran diversidad de recursos interacciónales y adaptan su conversación a diversos contextos institucionales. Aunque existe un interés creciente en cómo estos recursos varían en diferentes contextos, es escasa la investigación comparativa de los mecanismos de interacción en diferentes contextos. Es sobre estas líneas que este estudio, usando el Análisis de Conversación, se propone proporcionar una mirada de cómo un alumno de L2 manifiesta una diversidad observable en su aproximación a una tarea de discusión cara a cara y una tarea en línea. Nos enfocamos, turno por turno, en el primero encuentro del alumno con estos dos tipos de tareas y describimos las orientaciones del participante hacia una interacción sensible al contexto. Los hallazgos demuestran diferencias en la toma de turnos, la asignación, el diseño, y la implementación de sus acciones, contribuyendo así a la investigación de la competencia interaccional en la L2, basada en análisis comparativos de dos casos individuales.
\end{abstract}

Palabras clave: Análisis de la conversación; interacción orientada a tareas, competencia interaccional en la L2, sensibilidad al contexto, tipología de tareas 


\begin{abstract}
Resum
Investigacions recents sobre la interacció en la L2 i les competències interaccionals mostren que els alumnes de L2 despleguen una gran diversitat de recursos interaccionals i adapten la seva conversa a diversos contextos institucionals. Encara que hi ha un interès creixent en com aquests recursos varien en diferents contextos, és escassa la investigació comparativa dels mecanismes d'interacció en diferents contextos. És sobre aquestes línies que aquest estudi, usant l'Anàlisi de Conversa, es proposa proporcionar una mirada de com un alumne de L2 manifesta una diversitat observable en la seva aproximació a una tasca de discussió cara a cara i una tasca en línia. Ens enfoquem, torn per torn, en la primera trobada de l'alumne amb aquests dos tipus de tasques i descrivim les orientacions del participant cap a una interacció sensible al context. Les troballes demostren diferències en la presa de torns, l'assignació, el disseny, i la implementació de les seves accions, contribuint així a la investigació de la competència interaccional a la L2, basada en anàlisis comparatives de dos casos individuals.
\end{abstract}

Paraules clau: Anàlisi de la conversa; interacció orientada a tasques, competència interaccional a la L2, sensibilitat al context, tipologia de tasques

\title{
Introduction
}

Conversation analytic research on L2 interactions has increasingly diversified its contextual and institutional base, with more research on different L2s (e.g. Kunitz \& Markee, 2018 for Italian as L2; Çimenli \& Sert, 2017 for Turkish as L2), different types of classrooms (e.g. Käänta \& Kasper, 2017 for CLIL; Duran, 2017 for EMI), and a range of non-instructional environments (e.g. Eskildsen \& Theodorsdottir, 2017 for language learning in the wild) that include mobile augmented reality activities (Hellermann, Thorne \& Fodor, 2017) and online L2 tasks (Balaman \& Sert 2017a,b; Sert \& Balaman, 2017). Expanding the L2 database and maintaining a diversity of research settings is crucial for L2 researchers, as L2 users need to adapt their interactional competencies to locally contingent interactional dynamics in different settings and genres.

L2 Interactional resources, accomplishments, and competencies may unfold in different ways across contexts. Furthermore, different interactional accomplishments within locally situated practices can be co-constructed across different task types. L2 users adapt to such local contingencies that result from different task types. Researchers have suggested that the adaptation to local contingencies is in itself learning (Hellermann \& Pekarek Doehler, 2010). However, research that tracks individual L2 users' interactional achievements across different task types is scarce, and such line of research, we believe, is promising so as to understand (1) the adaptation of L2 users' linguistic repertoires to different contexts and (2) task-talk contingent affordances for language learning. Although constructs like task 
(interactional) difficulty (Pallotti, 2017) may play a major role in task accomplishment, tracking the same learner across two tasks in two distant times would prove useful in understanding the adaptation of interactional resources, as well as competencies. Against this background, we track one L2 (i.e. English) user across two task-oriented interactional contexts. We compare face-to-face discussion tasks with online emergent information gap tasks that seem to be two different, if not distant, task types.

\section{Literature Review}

Conversation Analysis (CA) has been informing L2 interaction research especially since the oft-cited position paper by Firth and Wagner (1997), which problematizes the cognitivist/interactionist understanding of SLA. In addition to critiquing the ways that L2 interaction data was collected, treated, and analyzed, Firth and Wagner promoted the use of CA for unpacking the role that social interaction plays over the course of L2 learning. They also paved the way for the emergence of a discipline bringing together the research interests of SLA and CA researchers, namely conversation analysis-for-second language acquisition (CA-for-SLA; Markee \& Kasper, 2004; CA-SLA, Kasper \& Wagner, 2011). A closer look into L2 learning in interaction also laid the ground for studies investigating the social practices that the learners accomplish in situ based on the co-construction of mutual understanding. Such accomplishment was reported to provide evidence for L2 interactional competence (IC) (cf. Hall, Pekarek Doehler \& Hellermann, 2011; Pekarek Doehler \& Pochon-Berger, 2015) as a construct for documenting L2 learners' interactional work at sequential level.

One of the main principles of CA is that any utterance in interaction is context-shaped and context-renewing (Heritage, 1984), which highlights the importance of the situated orientations to sequential actions as they are treated by the participants on a turn-by-turn basis. The situatedness of learner achievements is also considered as the main constituent of L2 IC in that the researchers following this line of inquiry draw heavily on context to describe learners' appropriation work in interaction (Pekarek Doehler, 2010; Hellermann, 2011). Accordingly, they also provide robust conversation analytic evidence to the interactional resources deployed for accomplishing social actions specific to the context (Hall \& Pekarek Doehler, 2011; Nguyen, 2011). Pekarek Doehler and Pochon-Berger (2015) refer to the management of routinized yet context-sensitive procedures to define L2 IC and establish the longitudinal diversification of members' methods for these procedures as well as an increased 
ability to deploy context-sensitive sequential and linguistic resources as the basis for interactional development in an L2 (Pekarek Doehler \& Berger, 2016). In a similar vein, Barraja-Rohan (2011) notes that L2 IC is "the ability to accomplish social actions befitting the interactional context" (p. 482). In his research on audio-based chat settings, Jenks (2014) focuses on the accomplishment of context-specific goals while describing the interactional unfolding of online interaction in his data with reference to IC.

To these ends, it can be claimed that L2 learners' adaptations to the interactional context (Pekarek Doehler, 2010) bring about a subsequent change in the ways that they manage the local contingencies of interaction (Pekarek Doehler \& Berger, 2016; Taguchi, 2014). Piirainen-Marsh and Tainio (2009) find evidence to such adaptation in the participants' interactional work to engage with the narrative on a gaming screen. Their research is a case in point to demonstrate how the contextual configurations are in play when co-constructing social actions (cf. Goodwin, 2000; 2013). The interplay between talk and other surrounding conduct is increasingly becoming a research interest for gaining a complete picture of how actions are formulated with an orientation to the context. Goodwin (2013) refers to the role that the context plays over the course of action formation by describing it as a layer within the multilayered, laminated body of the co-construction of action and knowledge. Balaman and Sert (2017b) adopt this conceptualization to describe the participants' orientations to a task interface for shaping the epistemics in online interactional setting. They report that the participants manage the context and knowledge co-construction in coordination by using the earlier as a resource for the latter.

The growing interest in the role of context is also reflected on research on institutional talk especially in L2 interactional settings. In line with the scope of the current paper, taskoriented interactional settings were investigated by a number of CA-for-SLA researchers (Hellerman, 2008; Hellerman \& Pekarek Doehler, 2010; Markee \& Kunitz, 2013; Mondada \& Pekarek Doehler, 2004; Mori, 2002; Seedhouse, 1999, 2005; Seedhouse \& Almutairi, 2009; Kunitz \& Skogmyr-Marian, 2017). All of these studies present descriptions of contextspecific interactional achievements oriented to pedagogical tasks at hand. Against this background, this study describes a focal participant's interactional management of two different task types in face-to-face and geographically dispersed settings. We document situated orientations to various contexts in a way to explicate context-sensitive conduct in L2 task-oriented interaction. To do that, the following section will initially explain these task types, the data collected from these settings, and briefly introduce Conversation Analysis. 
Following the analyses of the extracts showcasing the focal participants' first encounters with both tasks, we conclude the paper with a discussion on the potential contributions of a comparative investigation into L2 task-oriented interaction. We argue that this kind of inquiry will inform our understanding of L2 interactional competence based on observable learner achievements in situ.

\section{Method}

\section{Task descriptions and the corpora}

The data for this paper come from two different corpora. The first one is the L2 Discussion Tasks Corpus (L2DISCO, Sert 2016; 2017a, b), approximately 400,000 words corpus of L2 (i.e. English) group discussions audio recorded as part of an undergraduate level "Oral Communication Skills" course offered at a Turkish higher education institution. The corpus consists of 174 multi-party discussions and a total of 58 hours of audio recordings. Throughout two semesters, the first year undergraduate students recorded their group conversations at six different times from the beginning to the end of the year, discussing topics that they chose. The students, all L2 users of English, had all taken a central multiple choice university entrance language test that did not assess productive skills (writing and speaking) as well as listening, and was heavily grammar and vocabulary based. The majority of these students had gone through grammar and vocabulary oriented language education, with little or no emphasis on speaking or listening. The two semesters offered to these students for this class provided students with the opportunity to practice group conversations. The topics selected by the students ranged from the impact of technology to same sex marriage. The students, maintaining the same three or four members of their groups throughout the year, recorded their own conversations and reflected on them at the end of each semester on voluntary basis.

The second corpus is based on screen-recordings of online task-oriented interactions collected for a $\mathrm{PhD}$ project (Balaman, 2016) for over 18 weeks (i.e. 70 hours of interaction and 280 hours of on-screen activity). A total of 20 voluntary participants took part in the project to complete a total of 54 tasks (i.e. three tasks each week) uploaded to an online task interface which included three on-screen clues (i.e. a title, an audiovisual clue, and a textual clue). The participants met online using Google Hangouts and tried to complete tasks in groups of four in competition with other groups. The clues aimed to pave the way for the emergence of information gaps based on the participants' either on-site recognition or 
findings as result of collaborative web searches. The participants had similar backgrounds as described above although this project was not part of existing course work but was complementary as it aimed to improve interactional skills of L2 learners. Task completion within this setting was only possible when each member of a group found the correct answer and submitted it to the task interface. However, they were required to withhold the expression of the correct answer to one another and instead start adding new clues, thus engaging in hinting right after one of them found the correct answer (Balaman, 2016, Sert \& Balaman, 2017).

We use Conversation Analysis (Sacks, Schegloff, Jefferson, 1974) in order to explicate how speakers in each turn demonstrate to one another their own understanding of the previous speakers' turn (i.e. next-turn proof procedure). This also shows us, as the analysts, the participants' own (non)understanding at sequential and micro level detail. By unpacking how the participants understand each other (i.e. emic perspective) rather than what we interpret based on exogenous theories or researcher assumptions (i.e. etic perspective), we draw on fine-tuned transcriptions (see the Appendix for the Jeffersonian transcription system) that we produced to annotate temporality, suprasegmentals, verbal and visual conduct.

The level of detail in reproducing any given context in a transcription is crucial in CA research, since the participants' designs of turns, formations of actions and organization of sequences can be best depicted via a transcription system that does not dismiss any detail of interaction as irrelevant. Based on the transcriptions of naturally occurring talk-in-interaction, CA provides a complete picture of situated participant orientations mainly through the socioanalytic constructs such as turn-taking, sequence organization, preference organization, and repair. Having produced CA transcriptions and detailed analyses using both corpora (Balaman, 2016; Balaman \& Sert, 2017a, b; Sert, 2016; 2017a, b), we selected two single cases from each corpus to describe the locally contingent actions a particular, focal participant produces. Single case analyses of L2 (e.g. Balaman \& Sert, 2017a; Sert, 2017c; Waring, 2008) and L1 (e.g. Sert, Bozbıyık, Elçin \& Turan, 2015) interactions are not rare, and are found to be very useful as they demonstrate rich interactional phenomena with lots of analytic details based on a specific context. In selecting the single cases for comparative purposes, we made sure that there is a common participant in each corpus. Secondly, we tried to level the participants' engagement duration with each task: so both episodes come from the focal participant's first (recorded) encounter with the tasks. 


\section{Analysis}

Extract 1 comes from L2DISCO and is part of the first group discussion task interaction out of six recordings distributed over two semesters. The participants are talking about the impact of technology on society. Our focal participant in both of the extracts is EL. The following analysis highlights EL's locally managed turn design, turn taking and allocation practices which she fine-tunes for maintaining the progressivity of discussion task talk. The extract begins with EA's personal negative stance on technology addiction. In line 03, she explicitly marks the end of her turn (that's it) and therefore makes speaker transition relevant. After a long silence in line 04, she allocates the turn to our focal participant, EL, using a "what about + address term" formulation.

\section{Extract 1. EL's first encounter with discussion tasks (L2DISCO)}

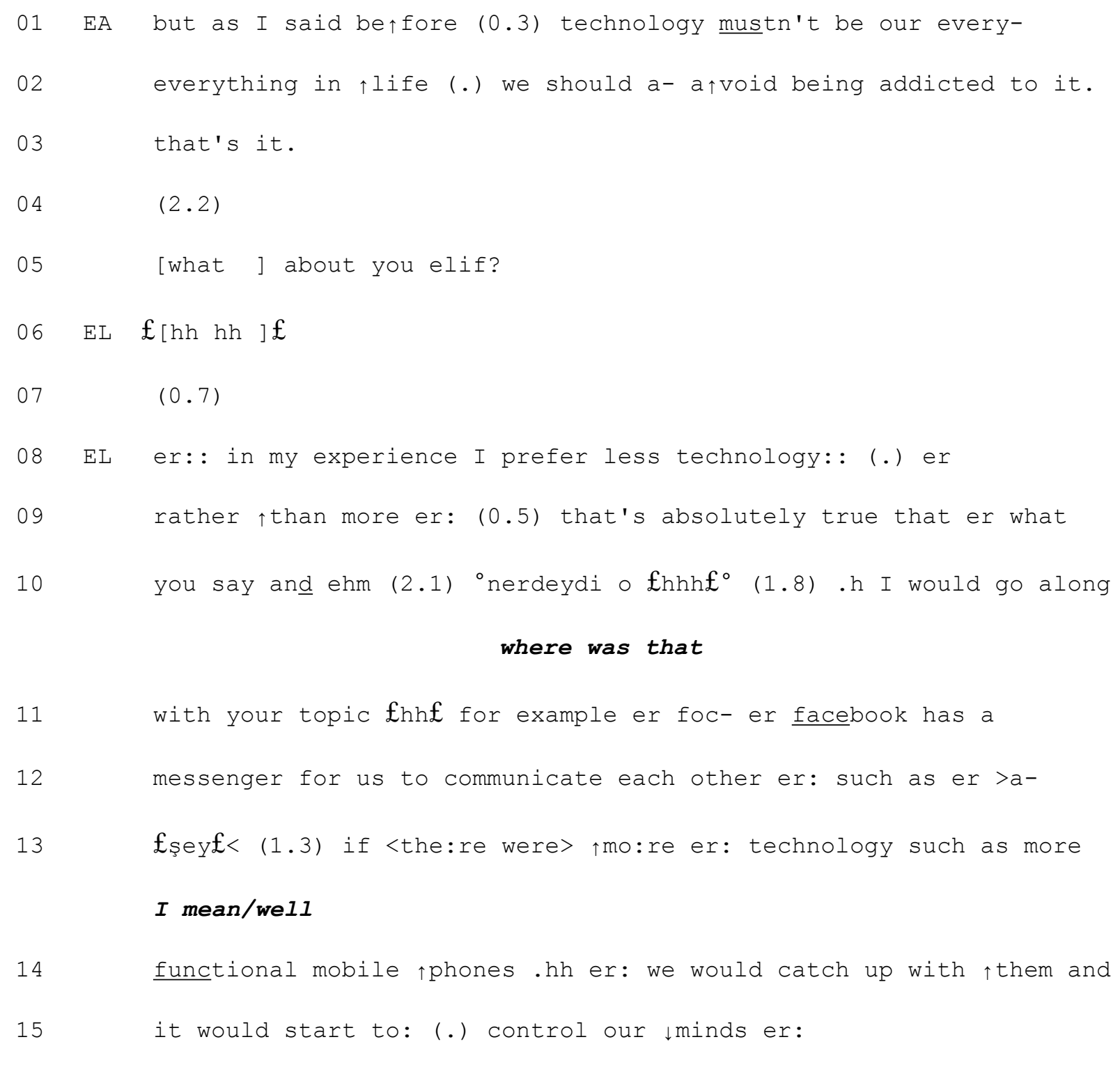




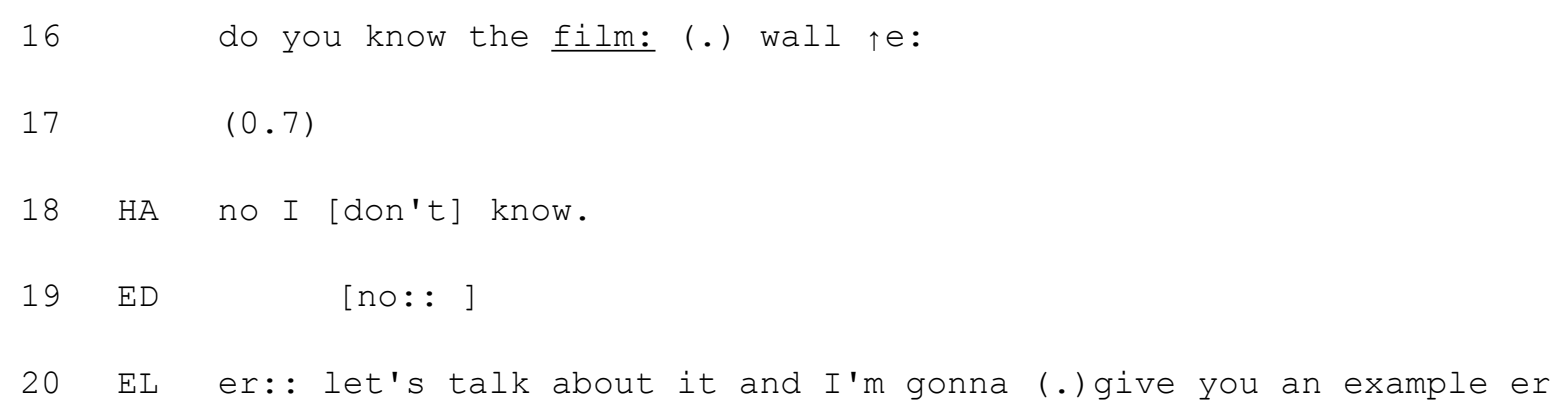

EL, in line 06, overlaps EA's individual nomination with a brief laughter, which precedes 0.7 second of silence before EL obtains the floor. In line 08, EL starts off her turn with a stretched hesitation marker and reports her preference for less technology in life, followed by an explicit formulaic (despite being ungrammatical) agreement (that's absolutely true that er what you say and ehm) in lines 09 and 10. This is followed by 2.1 seconds of silence, an explicit search marker in Turkish (tr: where was that?) produced quietly and with smiley voice - ${ }^{\circ}$ nerdeydi $\circ £$ hhh $\AA^{\circ}$, and another long silence in line 10 . Very long silences, word search, use of L1, sotto-voce production, and laughter indicate potential task-related trouble, resolved with a self-initiated self-repair as EL produces another explicit agreement formulation ( $\mathrm{I}$ would go along with $\mathrm{x}$ ). From lines 11 to 15 , she supports her argument by providing an example. Extended, long turns seem to be dominant in this interaction, with limited use of listenership tokens. In line 16, in order to maintain the topic, EL produces a knowledge check question to understand if her listeners are familiar with Wall E, an animation film. This question holds the listeners accountable to display (no/insufficient) knowledge, which is observable in lines 18 and 19 with HA's claim of insufficient knowledge (Sert \& Walsh, 2013) and ED's negative response token (no: :). EL uses the knowledge check-no knowledge display adjacency pair as a preface to her evolving topic management, which is explicitly marked with a suggestion and exemplification in line 20.

EL thus far has oriented to L2 discussion task talk through her demonstration of taskrelated trouble (Sandlund \& Sundqvist, 2011), demonstrable through a search for the formulaic language for agreement. Very long, extended turns also evidence EL's orientation to local contingencies of a discussion task. Furthermore, knowledge check questions also contribute to topic maintenance, which is a sine qua non of a discussion task, therefore is a part of the interactional repertoire that is context specific and locally contingent. From lines 21 to 26, EL elaborates on the new topic (Wall E). 
22

42 HA $={ }^{\circ}(\text { yeah })^{\circ}$

43 EL er: : (0.7) 个what are (.) they doing er when they are er

err: people start being away from each other and when they are get $\downarrow$ ting. hh $(0.6)$ er aware of $\uparrow$ that they realize what they have and what can be done without technology such as err: (.) >without

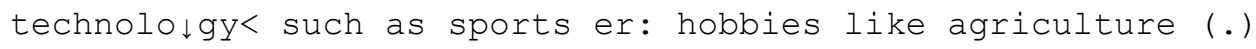
painting and.hh er: face to face communica ttion .hh and: what do you think ? e- hafize.

HA er: actually I- I'm agreeing with $\uparrow$ you: cause I prefer er less technology too $\uparrow$ cause (.) the technology is being more addicaddictive er in these $\uparrow$ days (.) I see addicted people around $\uparrow$ me: and this really disturbs me ehm: cause I even do this sometimes and I'm afraid of being like them (.) . hh maybe I'm >I don't know< sure $\downarrow$ y $\uparrow$ but er: I'm trying to hinder this situation (.) we need to see our faces, we need to touch each ot $\uparrow$ her. hh an:d (.) but it- in these $\uparrow$ days everything happens on the net I s- I see these .h er people started to forget er real $\uparrow$ things (.) er >I believe that we need to stop< being addicted to: (.) internet or mobile $\downarrow$ phones. $(0.7)$

EL er: : hafize you've said er that there are ehm: (0.7) addicted people around you:= using their mobile phones and er how they act how they be have.

In line 27, EL follows "the current speaker selects the next" norm and allocates the turn to HA. Note that both EA in line 05 and EL in 27 use the selected speaker's first name in turn final position in their turn allocation. In line 28, HA starts her turn with a hesitation marker and then produces an agreement token. In an extended turn, which now seems to be the institutional fingerprint of this discussion task-oriented talk, HA explains her stance on the 
use of the internet and mobile phones and criticizes addicted people until line 38. 0.7 second of silence follows HA's extended telling, and in line 40, EL obtains the floor with a stretched hesitation marker, addresses the previous speaker using her first name, and produces what looks like the first pair part of a pre-expansion, responded to by a confirmation by HA. In lines 43 and 44, again with a turn initial stretched hesitation marker (er: :), she asks a follow up question on the behaviours of technology addicted people, so as to maintain progressivity of task talk. Note that EL uses this turn initial device in all of her turns, be it first or second positioned.

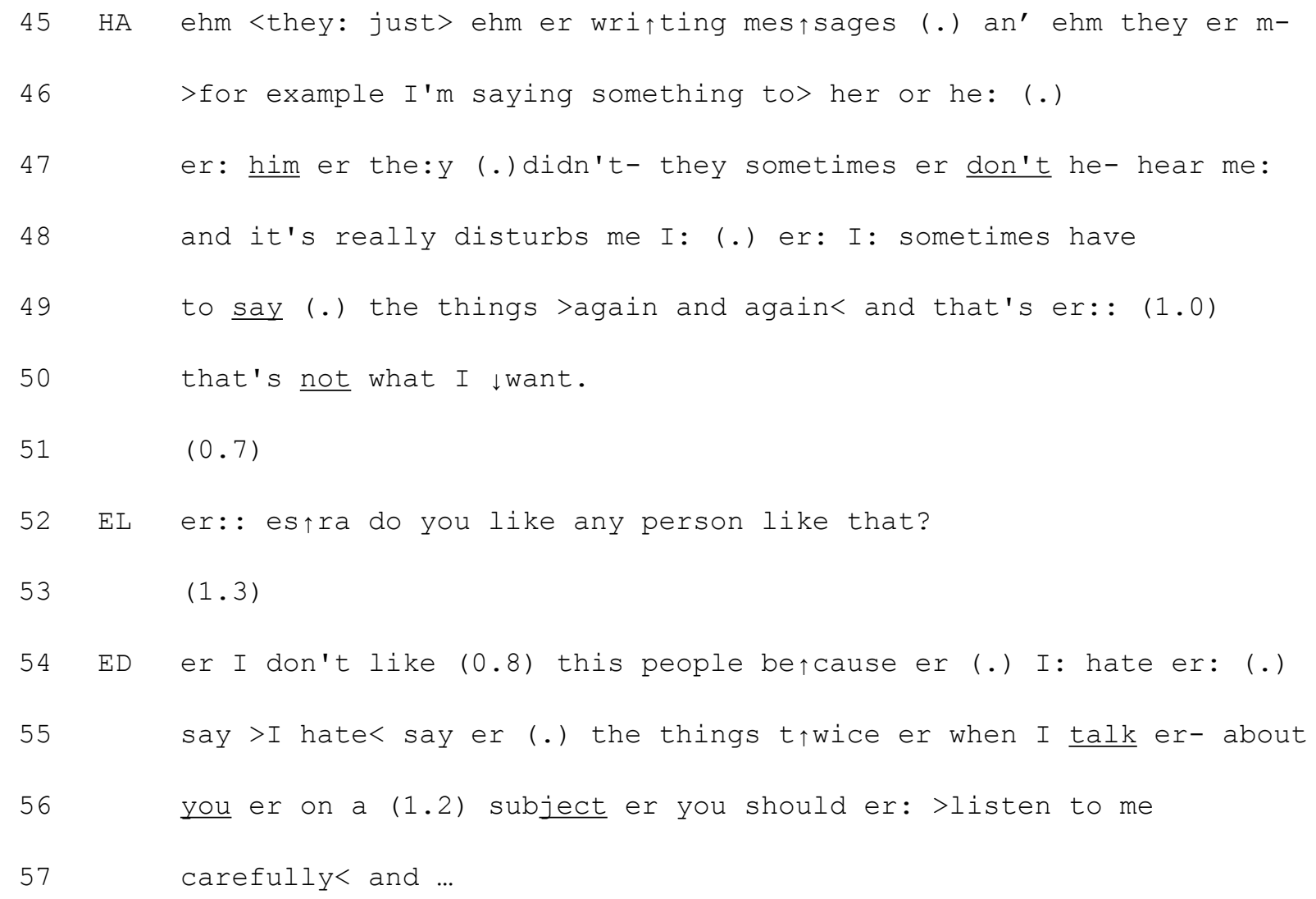

In her extended turn, from lines 45 to 49 , HA complains about the behaviours of technology addicts in response to EL's question. At the end of line 49, she explicitly formulates her personal stance. She first uses a deictic marker (that's) to refer to the behaviours she listed in her turn, then hesitates and stops for a second to self repair the grammar of her formulation. In line 50, she restarts her formulation and takes an explicit negative stance (that's not what I $\downarrow$ want), which functions as a case-closer for her. This closer marks the transition to another speaker, therefore, after 0.7 second of silence, EL self selects and allocates the turn to ED. Note that ED has only produced a negative response token in line 19, thus has not very actively, at least verbally, engaged in the ongoing 
discussion. EL, then, can be orienting to a moderator role by selecting the so-far-non-selected participant. She achieves this, not surprisingly, with a turn initial hesitation marker and using the first name of the selected participant as an address device. EL's question (er: : es $\uparrow$ ra do you like any person like that?) again successfully maintains the progressivity of the discussion task talk, displaying local, sequential, as well as topical contingency in a context sensitive manner.

Before we move on with EL's analysis of interactional accomplishments in another type of task, we would like to highlight the institutional fingerprints of her task-contingent resources: (1) extended turns that include tellings, (2) turn-initial stretched hesitation markers both in first and second positioned turns, (3) turn allocation practices, and (4) orientations to task-related troubles. The second extract comes from online information gap tasks corpus. EL is one of the participants again with three others, SIN, NUR, and ZEH. Similar to extract 1, it is the first encounter with the task interface as well as the task type, thus being comparable in nature. The second extract also contains a number of context-sensitive resources that explicate the situated orientations towards the task setting and the task type.

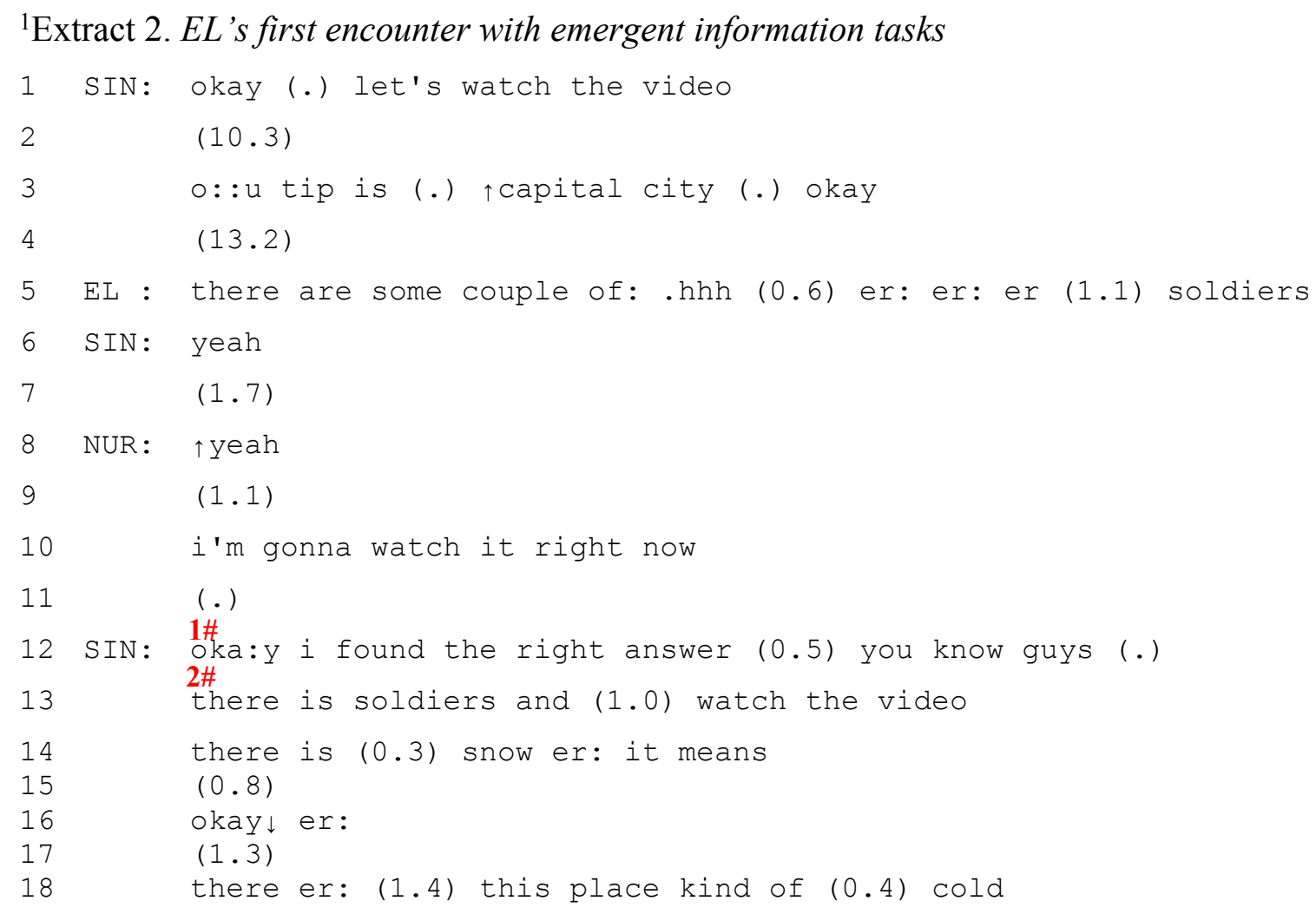

${ }^{1}$ Parts of Extract 2 also appeared in Balaman and Sert (2017a) with a different research focus. 


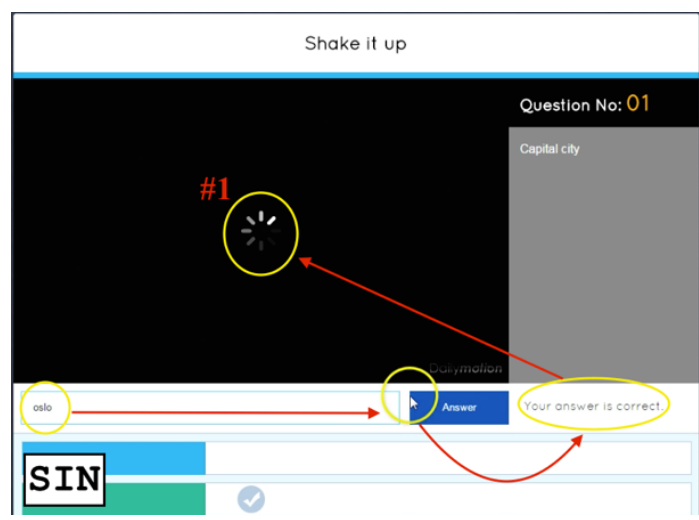

line 1- 1\# - Video player on SIN's screen loads after SIN types the correct answer, clicks on the answer button, and receives the correct answer feedback.

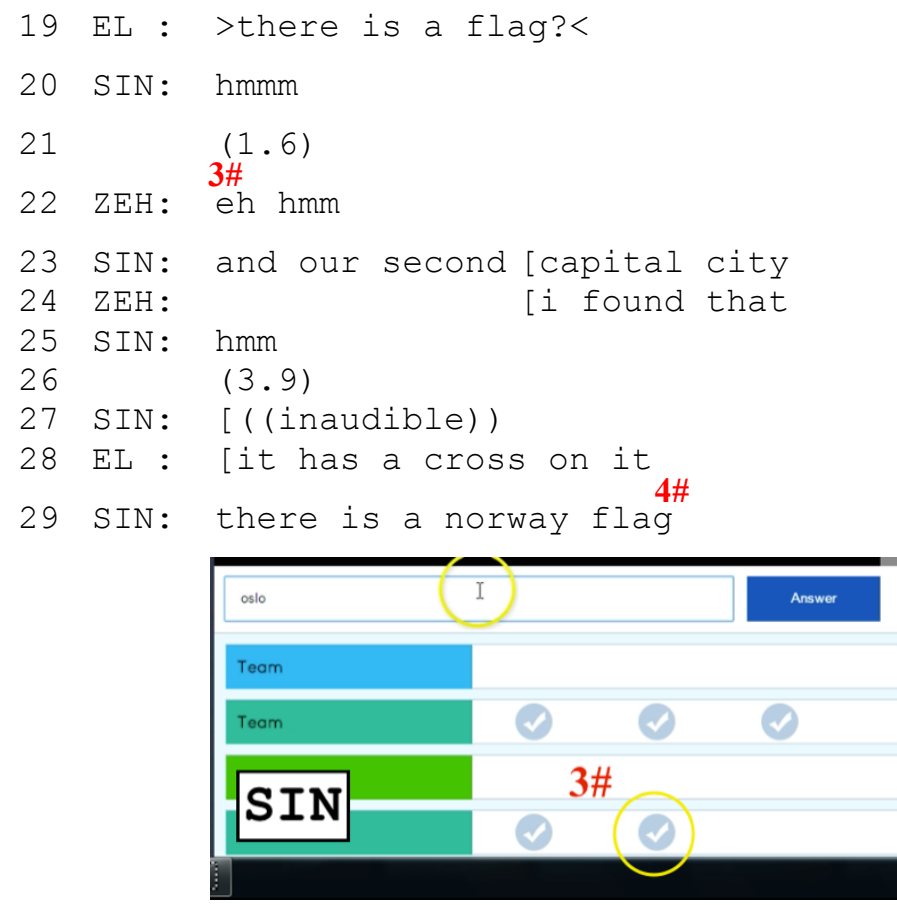

line 11- 3\# - ZEH's tick appears on the status chart as captured from SIN's screen.

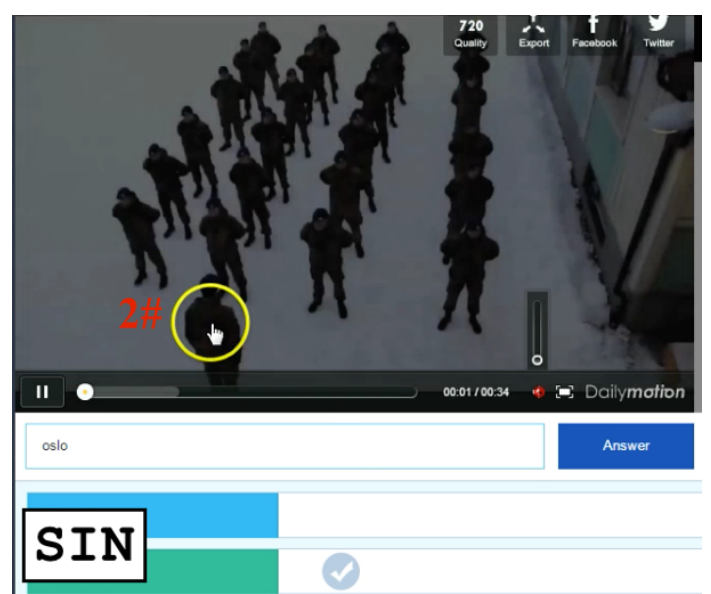

line 2- 2\# - The video starts playing and the soldiers appear on $2 \#$ in line 2.

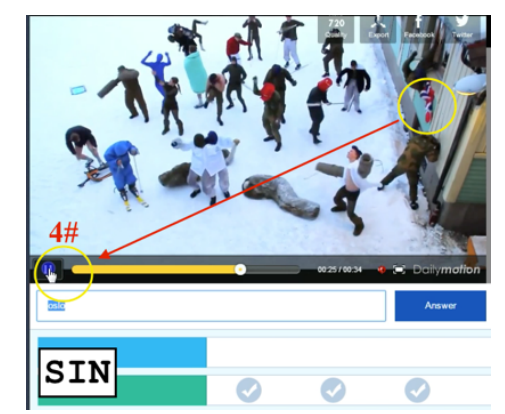

line 18-4\# - SIN pauses the video when the Norway flag appears for the first time. 
The extract starts with SIN's proposal of an action oriented to the audiovisual clue on the task interface in line 1, which is marked again in line 3 with her noticing of the textual clue. EL upgrades SIN's verbalization of the clues on the interface and starts describing the content of the video. Her description is limited in scope in that it only includes what is available in the thumbnail of the video as well as the rest of the video. It does not initiate any hinting sequences and solely functions to draw the co-participants' attention to something that they already have access to. Also note the long silences in lines 2 and 4 that potentially points to the ongoing orientations to the task interface as well as other context-sensitive screen-based resources. SIN and NUR orient to her description and NUR also reports that she is about to view the audiovisual clue. Thus far in the extract, the team does not make much progress in terms of task accomplishment yet successfully engages with the initiation of the task. In line 12, however, SIN announces that she has found the correct answer and initiates a hinting sequence with an extended description of the content of the video. EL orients to SIN's hinting with a request for confirmation in line 19 (>there is a flag?<). Her turn formation only targets specific information regarding the correct answer although the extended hinting turn does not have any references to a flag. Accordingly, SIN shows minimal orientation towards EL's request as can be observed with her continuation of hinting with a turn initial and in line 23, which overlaps with ZEH's announcement of finding the correct answer. What follows is that EL continues elaborating on the flag despite the lack of participant orientations, which finally pays off in line 29 when SIN mentions the flag for the first time in the extract (norway flag). Subsequently, EL formulates another confirmation request in line 31 ([ $\uparrow$ is it norway) in an overlapping fashion with NUR's similar action. Following the overlapping request and the silence, EL repeats her request in line 34, which is finally responded to with a double confirmation from the participants who have access to the correct answer.

Due to the nature of the task-oriented setting at hand which directs the participants to close the emergent information gaps for collaborative task accomplishment, the unknowing participants, including the focal participant EL, seem to produce to the point, rather short in length yet conditionally relevant turns (see lines 19, 28, 31, 32, 34). Similarly, these turns are designed to request confirmation and/or information from the knowing participants, which are responded with short turns once again. Given that the task accomplishment depends on finding a particular keyword, EL demonstrably tries to elicit information from the knowing participants to accomplish the task. This is also a mere reflection of the task type in the participants are expected to exchange information for task completion. EL, thus, shows her 
recognition of the institutional setting and brings this into interaction in coordination with the co-participants. We should also note that there is no room for turn allocation and turn-taking is managed in a self-selective manner. It can also be observed that there are no specific turntaking techniques unlike the previous extract. Based on the close analyses of two extracts and with specific focus on EL, the following table illustrates the context-sensitive differences of the two task types as well as the varying task-oriented settings.

\begin{tabular}{lll}
\hline Socio-analytical focus & L2 Discussion Tasks & $\begin{array}{l}\text { Online Emergent Information Gap } \\
\text { Tasks }\end{array}$ \\
\hline Turn design & Extended turns & short (to the point) turns \\
\hline $\begin{array}{l}\text { Action formation for } \\
\text { maintenance of } \\
\text { progressivity }\end{array}$ & $\begin{array}{l}\text { pre-expansions in the } \\
\text { form of, for example, } \\
\text { knowledge check } \\
\text { questions }\end{array}$ & Requests for confirmation/information \\
\hline Turn allocation & $\begin{array}{l}\text { Current speaker selects } \\
\text { next speaker; nomination } \\
\text { using first names }\end{array}$ & Self-selection \\
\hline Turn taking & $\begin{array}{l}\text { Turn-initial stretched } \\
\text { hesitation marker }\end{array}$ & No specific type \\
\hline Orientation to the setting & $\begin{array}{l}\text { Orientation to topic } \\
\text { maintenance }\end{array}$ & Orientation to on-screen activities \\
\hline Task-specific language & $\begin{array}{l}\text { Orientations to the use of } \\
\text { formulaic language to } \\
\text { formulate (dis)agreements }\end{array}$ & No specific goal \\
\hline
\end{tabular}

\section{Discussion and Conclusion}

Longitudinal studies (e.g. Cekaite, 2007; Hellermann, 2008) tracking L2 learners' increased diversification of interactional resources over time have been groundbreaking in research on language learning and beyond. Another potential site that deserves meticulous investigation is cross-contextual microanalytic explorations tracking one or more L2 users' deployment of interactional resources. Researchers can look into and compare, for instance, classroom interactions and language in the wild, or similar to what we did in the present study, they can compare a focal participants' interactional competencies in different tasks. There is no doubt that the participants in any given context, setting, or interactional event will go along with locally contingent action formations and will use their sequentially relevant, situated methods for producing actions in an L2. One may argue that it is impossible to compare one specific speech event with another, as the same event cannot be reproduced in the same way anyway. However, this is not the point.

Especially when it comes to tasks in L2, like in other institutional interactions, taskbased interactions produce and host their own fingerprints which can be tracked on sequential 
bases. In a discussion task, L2 users may produce extended turns, engage in a current speaker selects next speaker norm if they are still novice task interactants (see the analysis in extract 1), use formulaic language to (dis)agree, employ turn initial devices to obtain turns. In an online emergent information gap task (extract 2), however, different locally contingent actions may surface (e.g. self selection, shorter turns), again leaving the institutional fingerprints of this specific task type. As we show in our analysis, our focal L2 user adapted her interactional resources to the locally emergent, situated interactional routines motivated by the institutional goal orientations. She showed a level of interactional competence which is not necessarily developmental across time span, but maybe even more importantly, adaptable across contextual sensitivities. Having an understanding of the deployment of various interactional resources in different task settings can inform task design procedures in that task designers, mainly L2 teachers, could tailor different tasks for the improvement of some specific interactional skills. By doing that, it would be possible both to facilitate L2 interactional development and to increase L2 learners' context-sensitivity skills which might be transferred to further institutional settings.

Comparative $\mathrm{CA}$ has been concerned with cross-linguistic perspectives, and researchers have looked into phenomena like response design, repair, and embodied actions (see Sidnell, 2009). Markee's (2015) call for comparative reproduction research has also brought a new dimension to our understanding of comparison in CA research, especially in L2 interaction research. Likewise, we believe that comparisons of a focal participant's emergent interactional and institutional actions have lots to bring into research on L2 Interactional Competence. Different activities and tasks necessitate different interactional resources and an L2 user needs to deploy locally contingent actions in different settings. Going beyond tasks, we need to consider different genres, speech events, socio-linguistic dimensions (degree of formality etc.) and pragmatic needs of an L2 user going through a socialization process. Future CA databases that look into language development should then track learners across contexts as well as across time, to provide a more comprehensive picture for understanding the practices of language learning.

\section{References}

Balaman, U. (2016). A conversation analytic study on the development of interactional competence in English in an online task-oriented environment. Unpublished $\mathrm{PhD}$ Thesis. Hacettepe University. 
Balaman, U. \& Sert, O. (2017a). Development of L2 interactional resources for online collaborative task accomplishment. Computer Assisted Language Learning.

Balaman, U. \& Sert, O. (2017b). The coordination of online L2 interaction and orientations to task interface for epistemic progression. Journal of Pragmatics, 115, 115-129.

Barraja-Rohan, A. (2011). Using conversation analysis in the second language classroom to teach interactional competence. Language Teaching Research, 15(4), 479-507.

Cekaite, A. (2007). A child's development of interactional competence in a Swedish L2 classroom. The Modern Language Journal, 91(1), 45-62.

Çimenli, B. \& Sert, O. (2017). Orientations to Linguistic Form in Meaning and Fluency Contexts in a Turkish as a Foreign Language Classroom. In G. Schwab, S. Hoffmann and A. Schön (eds.), Interaktion im Fremdsprachenunterricht: Beiträge aus der empirischen Forschung (pp. 17-32). Münster: LIT Verlag.

Duran, D. (2017). Student initiated knowledge gaps in 'English as a medium of instruction' interaction in a higher education setting. Unpublished Doctoral Thesis. Hacettepe University.

Eskildsen, S. W., \& Theodórsdóttir, G. (2017). Constructing L2 learning spaces: Ways to achieve learning inside and outside the classroom. Applied Linguistics, 38(2), 143-164.

Firth, A., \& Wagner, J. (1997). On discourse, communication, and (some) fundamental concepts in SLA research. The Modern Language Journal, 81(3), 285-300.

Goodwin, C. (2000). Action and embodiment within situated human interaction. Journal of Pragmatics, 32(10), 1489-1522.

Goodwin, C. (2013). The co-operative, transformative organization of human action and knowledge. Journal of Pragmatics 46, 8-23.

Hall, J. K. \& Pekarek Doehler, S. (2011). L2 interactional competence and development. In J.K. Hall, J. Hellermann \& S. Pekarek Doehler (eds.), L2 interactional competence and development (pp. 1-15). Bristol, Buffalo, Toronto: Multilingual Matters.

Hall, J. K., Hellermann, J. \& Pekarek Doehler, S. (2011). L2 interactional competence and development. Bristol, Buffalo, Toronto: Multilingual Matters.

Hellermann, J. (2008). Social actions for classroom language learning. Clevedon: Multilingual Matters.

Hellermann, J. (2011). Members' methods, members' competencies: Looking for evidence of language learning in longitudinal investigations of other-initiated repair. In J.K. Hall, J. Hellermann \& S. Pekarek Doehler (eds.) L2 interactional competence and development (pp. 147-172). Bristol, Buffalo, Toronto: Multilingual Matters.

Hellermann, J. \& Pekarek Doehler, S. (2010). On the contingent nature of language-learning tasks. Classroom Discourse 1(1), 25-45.

Hellermann, J., Thorne, S. L., \& Fodor, P. (2017). Mobile reading as social and embodied practice. Classroom Discourse, 8(2), 99-121.

Heritage, J. 1984. Garfinkel and ethnomethodology. Cambridge: Polity Press.

Jenks, C. J. (2011). Transcribing talk and interaction: Issues in the representation of communication data. Amsterdam/Philadelphia: John Benjamins.

Jenks, C. J. (2014). Social interaction in second language chat rooms. Edinburgh: Edinburgh University Press.

Käänta, L., \& Kasper, G. (forthcoming, 2017). Students' self-initiated displays of (non)understanding in CLIL classroom interaction. Classroom Discourse.

Kunitz, S., \& Markee, N. (forthcoming, 2018). Teachers' instruction sequences in Italian as a foreign language classes: An ethnomethodological conversation analytic perspective. In (eds.) S. Kunitz, O. Sert \& N. Markee, Classroom-based conversation analytic research: Theoretical and applied perspectives on pedagogy. Springer. 
Kunitz, S., \& Skogmyr-Marian, K. (2017). Tracking immanent language learning behavior over time in task-based classroom work. TESOL Quarterly, 51(3), 507-535.

Markee, N. (2015) Are replication studies possible in qualitative second/foreign language classroom research? A call for comparative re-production research. Language Teaching, $1-17$.

Markee, N. \& Kasper, G. (2004). Classroom talks: an introduction. The Modern Language Journal, 88(4), 491-500.

Markee, N., \& Kunitz, S. (2013). Doing planning and task performance in second language acquisition: An ethnomethodological respecification. Language Learning, 63(4), 629664.

Mondada, L., \& Pekarek Doehler, S. (2004). Second language acquisition as situated practice: Task accomplishment in the French second language classroom. The Modern Language Journal, 88(4), 501-518.

Mori, J. (2002). Task design, plan, and development of talk-in-interaction: An analysis of a small group activity in a Japanese language classroom. Applied Linguistics 23(3), 323347.

Nguyen, H. T. (2011). Achieving recipient design longitudinally: Evidence from a pharmacy intern in patient consultations. In J.K. Hall, J. Hellermann \& S. Pekarek Doehler (eds.), L2 interactional competence and development (pp. 173-205). Bristol, Buffalo, Toronto: Multilingual Matters.

Pallotti, G. (2017). Assessing tasks: The case of interactional difficulty. Applied Linguistics. https://doi.org/10.1093/applin/amx020

Pekarek Doehler, S. (2010). Conceptual changes and methodological challenges: on language and learning from a conversation analytic perspective on SLA. In P. Seedhouse, S. Walsh, \& C. J. Jenks (eds.), Conceptualising 'learning' in applied linguistics (pp. 105126). Palgrave Macmillan UK.

Pekarek Doehler, S., \& Berger, E. (2016). L2 interactional competence as increased ability for context-sensitive conduct: A longitudinal study of story-openings. Applied Linguistics. https://doi.org/10.1093/applin/amw021

Pekarek Doehler, S., \& Pochon-Berger, E. (2015). The development of L2 interactional competence: evidence from turn-taking organization, sequence organization, repair organization and preference organization. In T. Cadierno \& S. W. Eskildsen (eds.) Usage-based perspectives on second language learning (pp. 233-270). Berlin: De Gruyter Mouton.

Piirainen-Marsh, A., \& Tainio, L. (2009) Collaborative game-play as a site for participation and situated learning of a second language. Scandinavian Journal of Educational Research, 53(2), 167-183

Sacks, H., Schegloff, E. A., \& Jefferson, G. (1974). A simplest systematics for the organization of turn-taking for conversation. Language, 50(4), 696-735.

Sandlund, E., \& Sundqvist, P. (2011). Managing task-related trouble in L2 oral proficiency tests: Contrasting interaction data and rater assessment. Novitas-ROYAL, 5(1), 91-120.

Seedhouse, P. (1999). Task-based interaction. ELT Journal 53(3), 149-156.

Seedhouse, P. (2005). Task as research construct. Language Learning 55(3), 533-570.

Seedhouse, P., \& Almutairi, S. (2009). A holistic approach to task-based interaction. International Journal of Applied Linguistics 19(3), 311-338.

Sert, O. (2016). Active listenership as an indicator of L2 interactional competence: Insights from an "oral communication skills" course. Symposium on the teaching and testing of L2 interactional competence, 29 April - 1 May 2016, Rice University, Houston. 
Sert, O. (2017a). Tracking an L2 speaker's use of complementizer that in discussion tasks. Thinking, Doing, Learning Conference 2017. 19-21 April, 2017. Ludwig Maximilians University, Munich, Germany.

Sert, O. (2017b). The interplay between collaborative sequences and active listenership: implications for 12 interactional competence. 15th International Pragmatics Conference. 16-21 July, 2017. Belfast.

Sert, O. (2017c). Creating opportunities for 12 learning in a prediction activity. System, 70, $14-25$.

Sert, O., Bozbıyık, M., Elçin, M., \& Turan, S. (2015). Standart hasta-tıp öğrencisi etkileşiminde ön bilgi iddiaları ve etkileşimsel sorunlar. Mersin Üniversitesi Dil ve Edebiyat Dergisi, 12(2), 73-94.

Sert, O. \& Balaman, U. (in press, 2017). Orientations to negotiated language and task rules in online L2 interaction. ReCALL.

Sert, O., \& Walsh, S. (2013). The interactional management of claims of insufficient knowledge in English language classrooms. Language and Education, 27(6), 542-565.

Sidnell, J. (Ed.). (2009). Conversation analysis: Comparative perspectives. Cambridge University Press.

Taguchi, N. (2014). Development of interactional competence in Japanese as a second language: Use of incomplete sentences as interactional resources. The Modern Language Journal, 98(2), 518-535.

Waring, H. Z. (2008). Using explicit positive assessment in the language classroom: IRF, feedback, and learning opportunities. The Modern Language Journal, 92(4), 577-594.

Appendix: Transcription Conventions

\section{JEFFERSON TRANSCRIPTION CONVENTIONS}

\begin{tabular}{ll}
\hline[] & Overlapping utterances - (beginning [) and (end]) \\
\hline $\mathbf{( 0 . 4 )}$ & Contiguous utterances (or continuation of the same turn) \\
\hline $\mathbf{( . )}$ & Represent the tenths of a second between utterances \\
\hline $\mathbf{E}$ & Represents a micro-pause (1 tenth of a second or less) \\
\hline- & Elongation (more colons demonstrate longer stretches of sound) \\
\hline $\mathbf{P}$ & Fall in pitch at the end of an utterance \\
\hline CAPITAL & An abrupt stop in articulation \\
\hline & Rising in pitch at utterance end (not necessarily a question) \\
\hline$\uparrow \downarrow$ & Loud/forte speech \\
\hline o o & Underline letters/words indicate accentuation \\
\hline $\mathbf{h h h}$ & Marked upstep/downstep in intonation \\
\hline $\mathbf{h h h}$ & Surrounds talk that is quieter \\
\hline $\mathbf{h e ~ o r ~ h a}$ & Exhalations \\
\hline $\mathbf{( h h h )}$ & Inhalations \\
\hline$><$ & Laugh particle \\
\hline$<>$ & Laughter within a word (can also represent audible aspirations) \\
\hline $\mathbf{( ( ) )}$ & Surrounds talk that is spoken faster \\
\hline $\mathbf{( )}$ & Surrounds talk that is spoken slower \\
\hline $\mathbf{S ~}$ & Analyst notes \\
\hline
\end{tabular}


Adapted from Jenks (2011)

\begin{tabular}{ll}
\hline $\mathbf{l}$ & $\begin{array}{l}\text { Onset point of the on-screen activity surrounding the talk that is marked along } \\
\text { with the lines of the transcript }\end{array}$ \\
\hline$\# \boldsymbol{1}$ & $\begin{array}{l}\text { Offset point of the on-screen activity surrounding the talk that is marked along } \\
\text { with the lines of the transcript }\end{array}$ \\
\hline $\mathbf{l}$... & $\begin{array}{l}\text { Continuation of the on-screen activity (used only within the on-screen activity } \\
\text { illustrations) }\end{array}$ \\
\hline Illustrations & Current web page(s) of the participants who perform the on-screen activities \\
\hline Circles & Points on the screen which the participants either click or hold the cursor still \\
\hline Arrow & Direction of the cursor movements within the on-screen activity illustrations \\
\hline line 2-5 & $\begin{array}{l}\text { Duration of on-screen activity represented across lines in order to indicate the } \\
\text { scope of each description }\end{array}$ \\
\hline Descriptions & $\begin{array}{l}\text { Unanalytical descriptions of the illustrated on-screen activities which are } \\
\text { provided following the offset point of the on-screen activity }\end{array}$ \\
\hline Excerpted from Balaman \& Sert (2017a; b)
\end{tabular}

\begin{abstract}
Authors' information:
Ufuk Balaman is based in the department of English Language Teaching at Hacettepe University, Turkey. He is also the vice-director of Hacettepe University Micro-Analysis Network (HUMAN) Research Centre. His research primarily deals with online task-oriented L2 interaction using conversation analysis as the research methodology. His recent publications have appeared in Computer Assisted Language Learning, ReCALL, and Journal of Pragmatics.

Email: ubalaman@gmail.com

Olcay Sert is the editor of Classroom Discourse (Routledge) and is the author of Social Interaction and L2 Classroom Discourse (Edinburgh University Press), which was shortlisted for the BAAL Book Prize in 2016 and became a finalist for the AAAL first book award in 2017. He is co-editing (with Silvia Kunitz and Numa Markee) a volume entitled Classroom-based Conversation Analytic Research: Theoretical and Applied Perspectives on Pedagogy, which will be published by Springer in 2018. He has published on classroom interaction and interactional competence in various journals, including the Journal of Pragmatics, TESOL Quarterly, System, and Computer Assisted Language Learning. He is acting as a reviewer for journals like Applied Linguistics, Modern Language Journal, ROLSI, and Language Learning.
\end{abstract}

To cite this article:

Balaman, U., \& Sert, O. (2017). Local contingencies in L2 tasks: A comparison of context-sensitive interactional achievements across two different task types. Bellaterra Journal of Teaching \& Learning Language \& Literature, 10(3), 9-27. DOI: http://doi.org/10.5565/rev/jt13.746

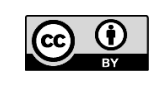

